Regards sur l'économie allemande

Bulletin économique du CIRAC

$89 \mid 2008$

Varia

\title{
Helmut Schmidt : l'hommage de la chancelière
}

\author{
Isabelle Bourgeois
}

\section{OpenEdition}

Journals

Édition électronique

URL : http://journals.openedition.org/rea/2983

DOI : $10.4000 /$ rea.2983

ISBN : 978-2-8218-0874-4

ISSN : 1965-0787

Éditeur

CIRAC

Édition imprimée

Date de publication : 1 décembre 2008

Pagination : 38

ISSN : 1156-8992

Référence électronique

Isabelle Bourgeois, " Helmut Schmidt : I'hommage de la chancelière », Regards sur l'économie allemande [En ligne], 89 | décembre 2008, mis en ligne le 01 décembre 2010, consulté le 15 septembre 2020. URL : http://journals.openedition.org/rea/2983

Ce document a été généré automatiquement le 15 septembre 2020.

(C) CIRAC 


\title{
Helmut Schmidt : l'hommage de la chancelière
}

\author{
Isabelle Bourgeois
}

Le 23 décembre, Helmut Schmidt fêtera ses 90 ans. La République fédérale rendra hommage à cet ex-chancelier (SPD) qui dirigea l'Allemagne à une époque charnière (1974/82). Au plus fort des années noires de la RAF, cet homme de valeurs mit tout en œuvre pour concilier défense d'une jeune démocratie et répression du terrorisme. A la suite de la crise de 1973, il sut se laisser convaincre par Valéry Giscard d'Estaing d'instaurer le système monétaire européen de fluctuation concertée des monnaies préfiguration de l'Union monétaire qui, dans la crise actuelle, prémunit les économies de la zone euro contre les risques monétaires au sein de l'UE. H. Schmidt, qui n'a jamais quitté l'espace public, dirige toujours l'hebdomadaire Die Zeit, où il prend sa plume pour défendre les valeurs au fondement du "modèle rhénan ", ainsi lorsque, en août 2004, il plaide pour des réformes structurelles, seules à même de rétablir l'équilibre entre solidarité et richesse, prenant ouvertement la défense d'un chancelier Schröder (SPD) accusé notamment par la gauche du SPD de' 'démanteler' les acquis sociaux. Et, libéral car ardent défenseur des libertés, il livre aujourd'hui toutes les semaines ses réflexions aux lecteurs de Zeit Magazin, supplément de son journal, sous forme d'entretien dans une rubrique intitulée avec cet humour foncier qui le caractérise: "Le temps d'une cigarette avec Helmut Schmidt». Et c'est Die Zeit (11-12-08) que la chancelière Angela Merkel (CDU) a choisi pour lui rendre un respectueux hommage : "Helmut Schmidt a toujours cru dans la force de la liberté et de la démocratie, ce qui a fait de lui une des personnalités les plus marquantes et les plus respectées de la RFA » (IB). 
INDEX

Mots-clés : chancelier, homme politique, pouvoir politique, Helmut Schmidt, SPD 